Article

\title{
Archaeology and Folk or Family Religion in Ancient Israel
}

\author{
William G. Dever \\ Lycoming College, Williamsport, PA 17701, USA; gaber@lycoming.edu \\ Received: 14 November 2019; Accepted: 26 November 2019; Published: 12 December 2019
}

check for updates

\begin{abstract}
This article will summarize and interpret archaeological data that may be used to illuminate the religion of ancient Israel, ca. 1200-600 BCE, while using a phenomenal approach. The resultant portrait will be compared with one drawn from the texts of the Hebrew Bible, which suggests both convergences and significant differences. The conclusion will emphasize that archaeology does best in providing a real-life context for both artifact and texts. However, it is mostly limited to religious practice, rather than belief.
\end{abstract}

Keywords: ancient Israel; Israelite religion; folk religion; family religion

\section{Introduction}

This discussion will focus on how recent archaeological excavation and research may affect our understanding or religious beliefs and practices in ancient Israel during the settlement era and the monarchy, ca. 1200-600 BCE. In particular, we shall contrast a portrait that is based on material culture remains with that derived from texts, i.e., primarily those of the Hebrew Bible.

\section{Defining Terms, and Some Caveats}

"Religion" is notoriously difficult to define; but, for the purposes of discussion, we shall regard religion here as:

A structured set of beliefs, values, symbols, and ritual practices that strives to relate the individual and society to the numinous, or the realm of the gods, perceived as the ultimate reality and authority.

A further distinction can be made, if only for heuristic reasons. The phenomenon of religion, whatever the individual peculiarities, can be analyzed by separating (1) belief and (2) practice. Such a separation has been criticized in principle, but its usefulness cannot be denied.

The former, or belief, is often systematized as theology, being usually enshrined in sacred texts, or Scripture, and overseen by clerics. This more abstract but institutionalized aspect of religion is sometimes described as "orthodoxy", presumably in contrast to more popular "folk" religion, as practiced by the majority (Ackerman 1992, pp. 1-2). The formal and institutionalized expression of religion has also been aptly characterized as "book religion" (Van der Toorn 1996, passim).

This is the "religion" of the Hebrew Bible-the ideal, never the reality throughout the Iron Age. It is the vision that is exalted of the handful of elites who wrote the Hebrew Bible. They sought to shape not only theology, but also the cult. Yet, "cult" is practice, what the majority of the population was actually doing. The real religion(s) of ancient Israel largely consisted of everything that the biblical writers condemned.

In recent discussions of the topic here, the latter, or "folk religion", is usually termed "family" or "household" religion, the focus being on what archaeology is best equipped to observe: the actual, widespread practice of religion at the household level.

Van der Toorn seems to be the first to have advanced the term "family religion" (Van der Toorn 1996). However, Berlinerblau, along with others, had already questioned such dichotomies as 
"popular" vs. "official" (Berlinerblau 1996). Earlier Holladay had coined the term "non-conformist" (Holladay 1987), but it did not find any support.

Not all the widespread practices of religion can be subsumed under the rubric of "family/household religion". What these practices have in common is that they are "non-orthodox", that is, not in conformity with what we shall call here "book religion" (following van der Toorn). Thus, Holladay's suggestion has some merit.

Now, there are a number of synthetic works employing the rubric of "family religion", (see Bodel and Olyan 2008; Albertz and Schmitt 2012; Dever 2017; and, especially many of the essays in Albertz 2014).

As we shall see, the archaeological evidence at our disposal rarely adds anything relevant to orthodox theology, except to describe in passing the historical and socio-cultural context in which the canonical texts may have first taken shape. None of that contextual information, however comprehensive, can explain or legitimize what becomes the official religion. Even that minimal contribution is only possible if the religion in question is (or claims to be) "historical". Archaeology can deal quite well with material culture remains-the physical—but by definition it cannot deal with metaphysical phenomena. Therefore, archaeology cannot comment on early Islam, because, despite the claims of traditional, non-critical Muslim historiographers, there is no known historical context of Muhammed's early life, or the composition of the Koran, or the initial spread of Islam. In contrast, since the mid-19 cent., Judaism and Christianity—both claiming to be "historical religions" —have been subjected to rigorous critical scrutiny with regard to their Scriptures. However, Islam has escaped any such scrutiny, so hoping to excavate the Qibla in Mecca, or "Muhammed's birthplace", would be irrelevant. There are some archaeological commentaries on early Judaism and Christianity, but they are beyond our purview here.

Religion, in whatever form it takes, largely deals with the metaphysical, while archaeology deals specifically with the physical world. To be sure, we assume that the things humans make and use faithfully embody their behavior, and therefore reflect their thoughts. Nevertheless, such data can only be inferred, and in any case remain speculative. As Binford reminded us, archaeologists are poorly equipped to be paleo-psychologists (Binford 1982, pp. 162-63).

Here, we shall employ a phenomenological approach that is sometimes called "functionalism", because it focuses more on what societies actually do than upon larger social theories.

Let us specify further what we mean by a "phenomenological" or "functionalist" approach. Such an approach operates, as follows:

1. It relies upon observing society directly, in action rather than in theory.

2. It does not necessarily "reconstruct", but uses typical case studies.

3. It seeks to understand society "from within" - what folks say about themselves - whether through words or symbolic actions.

4. It emphasizes individual creativity, rather than trying to develop large-scale "typologies".

5. Its objective is Geertz (1973) "thick description", not necessarily explanation.

6. It makes use of "organic models", assuming that social systems operate in some ways like biological systems (notions of interacting "subsystems", seeking and maintaining equilibrium).

7. Its methods are basically inductive, that is, working from the particular to the general, rather than deductive, or seeking "law-like generalizations".

8. It does not eschew ideology, but it assumes that the exact content of belief systems is irretrievable, although their observation is possible through inference.

\section{Previous Scholarship}

Israelite religion, like Christianity, is usually considered to be "historical", that is, rooted not in moral philosophy, or merely a sociological construct, but is instead derived from an empirically documented historical context. In our case, that would be the Iron Age in the southern Levant 
ca. $1200-600$ BCE, specifically the area that is now occupied by the modern state of Israel plus the West Bank.

Despite some skeptical voices, the political, socio-economic, and cultural history of a real-life "ancient Israel" in the Iron Age in this region can now be written with some confidence-especially when the archaeological data, not the biblical texts, are taken as the primary evidence. The texts then become secondary, of limited value.

Yet, history-writing in biblical studies has not flourished in many years. That is due to the "literary turn" in biblical studies—-that is, a turn away from history-writing-which has been heavily influenced by postmodernism (Dever 2001a, pp. 1-52; see also state-of-the art treatments in Barr 2000; Collins 2005). However, we now have the first archaeologically-based history of ancient Israel, with full references to earlier literature (Dever 2017).

Ever since the beginning of modern biblical scholarship in the mid-19th century, scholars of the Hebrew Bible have assumed that the goal was first a comparative critical understanding of the text; then, based on that achievement, a more accurate history of ancient Israel; and, finally, an authoritative portrait of what was considered to be the final, enduring contribution of the Hebrew Bible: its religion. This was clearly a project of the Enlightenment, which was an essential part of the foundations of the "Western cultural tradition" (now much maligned; cf. Tarnas 1991; Gress 1998).

Not surprisingly, from the mid-19th cent. onward, numerous ambitious "histories of ancient Israelite religion" appeared. However, until the early 20th cent., none had the advantage of possessing the only possible external evidence, which was increasingly supplied by archaeology as it came of age. Most of these works were little better than paraphrases of the Hebrew Bible and thus largely useless. More lamentable still, many were Christian "Old Testament theologies"—-modern dogmatic constructs read back into the Hebrew Bible.

With no new data, works of the Religions geschicte school and of various theological and sociological approaches eventually ran out of steam. Not until recently has archaeology inspired a revival of interest in ancient Israelite religion. Even so, up to now, only a few works on Israelite religion have attempted to synthesize the burgeoning archaeological data. Among the first was Zevit's The Religions of Ancient Israel: A Parallactic Approach (Zevit 2001); and, Dever, Did God Have a Wife? Archaeology and Folk Religion in Ancient Israel (Dever 2005). These were followed in 2012 by the collaboration of two German biblicists, Albertz and Schmitt, Family and Household Religion in Ancient Israel and the Levant, a remarkably thorough work by non-specialists in archaeology.

There are also now a few other works on specific topics, as well as some brief surveys here and there. Curiously, there are no significant publications by Israeli archaeologists, although they are the closest to the data, but the reasons are beyond our purview here. Israeli archaeologists, almost all secularists, are no doubt negatively influenced by the hostility of the Orthodox toward them and their work. Thus, they tend to avoid the subject of religion altogether.

\section{An Archaeological and Phenomenological Portrait}

Turning now to recent specific archaeological data that may best illuminate the religions (sic) of ancient Israel, we shall take what we have called above a "phenomenological" approach. We must recognize that writing the history of such a religion (or any other) is beyond the limits of our evidence, even though the archaeological data are more dynamic than the biblical text,, being frozen as it is in one point in time.

This survey of the realia must be cursory and the bibliographic references kept to a minimum. We shall organize the discussion in terms of the specific categories of material culture remains.

\subsection{Temples}

We have no direct archaeological evidence of the only temple that the Hebrew Bible recognizes, which was supposedly constructed in Jerusalem by Solomon in the 10th cent. BCE. The Temple Mount has never been excavated for obvious reasons. The elaborate description in II Kings contains many 
obscure Hebrew terms. Thus, such a temple long seemed fanciful. Yet, today we have more than two dozen Bronze and Iron Age monumental Canaanite, Phoenician, Aramean, and other temples in the Levant. They provide close parallels for the plan and nearly all the decorations and furnishings of the fabled Solomonic temple (see Meyers 1992; Dever 2001a, pp. 144-47; Dever 2005, pp. 96-98; Bloch-Smith 2002; Monson 2000; Monson 2005).

The only excavated ancient Israelite temple was found in the 1960s at Arad, east of Beersheba' dating to the 8th cent. BCE. Like the Jerusalem temple, it has a tripartite plan. In the outer, open courtyard, there is a large altar made of unhewn stones (fitting the biblical requirement). A small bronze lion was found on a low stone bench at the foot of the altar, a token animal that is associated with the old Canaanite Mother Goddess "Asherah" (below).

Flanking the entrance to the small inner sanctum (Heb. dĕvir) were two stylized four-horned incense altars. On the back wall stood two (originally three) large standing stones, with the biblical māṣsēbôth, usually commemorating the appearance or presence of a deity-in this case, notably a pair of deities (below).

Among the other finds at Arad was a Hebrew ostracon (inscribed potsherd) that referred to "the temple of Yahweh", with Yahweh being the name of Israel's national deity here, presumably the temple at Arad. Other Arad ostraca contain the personal names of priestly families that are known from the Bible.

The standing stones were found not in situ, but carefully laid down under a secondary floor and plastered over, perhaps in the 7th cent. BCE. Some have taken this as evidence of the cult reforms attributed to King Josiah, described in detail in II Kings 23. Among his efforts was the removal from cult places the "asherahs", tree-like symbols of the goddess Asherah. If so, the Arad standing stones likely represent Yahweh and his consort Asherah (or perhaps three deities; below, see provisionally Herzog 2001; Herzog 2002; Na'aman 2002; Dever 2017, p. 497; cf. generally Zevit 2001, pp. 169-71; Dever 2005, pp. 170-75; Albertz and Schmitt 2012, pp. 123-25).

\subsection{Regional Sanctuaries}

According to the orthodox program of the biblical writers, there is only one official sanctuary, the temple in Jerusalem-although the vociferous condemnation of other sanctuaries is the best proof of their existence.

At Dan, on the extreme northern border with Israel (still today), an entire cultic complex was found, one that probably served as a regional sanctuary in the 10th-8th cent. BCE, when Dan was, in effect, the cultural capital of the northern kingdom of Israel.

The principal installations at Dan were an altar in the gate plaza with five small standing stones (Heb. māsșēbôth) and several offering bowls; a large elevated dressed stone platform, approached by a flight of steps, evidently the biblical "high place" (Heb. bāmāh), which is usually condemned as "Canaanite"; fragments of a monumental stone four-horned altar, as well as a smaller broken altar; an olive-pressing installation, for producing the appropriate oils for liturgical uses; a bronze workshop that produced, among other things, a fine offering bowl and a priestly scepter head; ceramic offering stands and bowls; and, both male and female figurines.

The Dan cult complex is a parade example of the regional sanctuaries that the Hebrew Bible expressly forbids, the ideal being, a single, central royal sanctuary in Jerusalem. In the hill country of Ephraim and Manasseh to the south, the "Bull Site" is an isolated hilltop sanctuary of the 10th century BCE. At Dan, there was even a functioning priesthood, as opposed to the official Jerusalem Levitical priests. (The material is only partially published; but see Biran 1994; Arie 2008; Zevit 2001, pp. 180-96; Dever 2005, pp. 139-51; Albertz and Schmitt 2012, pp. 221-38).

At Tell el-Farah in the Samaria hillcountry, northern Israel's first capital Tirzeh, another regional cult center was found. It featured a city gate shrine with a large standing stone and an olive press or basin; and, small finds, such as female figurines and a naos or terra cotta model temple of the sort that is usually associated with the goddess Asherah. The prominence of the gate installation, where 
many people customarily came and went, shows that this, like the Dan shrine, served a larger region. Its features included a temenos or stone enclosure wall; a paved platform; a standing stone; an altar (?); bronze, silver, and ceramic fragments; animal bones; and, a perfectly preserved bronze Zebu bull of Anatolian type, like an earlier Canaanite one found at Hazor. In the Canaanite pantheon the epithet of the principal male deity El was "Bull", the bull being an old symbol of both fertility and ferocity (Zevit 2001, pp. 176-80; Dever 2005, pp. 135-36; Albertz and Schmitt 2012, p. 234).

In Judah to the south, Cult Room 49 at Lachish, belonging to the 9th cent. BCE (the early monarchy) features a rectangular building with low benches around the walls. It was found to be filled with terra cotta offering stands; various kinds of cultic vessels; and, small stylized four-horned incense altars. Its public location suggests that it may have served a relatively large clientele (Zevit 2001, pp. 213-18; Dever 2005, pp. 116-17; Albertz and Schmitt 2012, pp. 123-25).

\subsection{Neighborhood Shrines}

These are smaller shrines, usually in small town and villages. One such installation is at Ta'anach, near Megiddo in the Jezreel Valley region, which dates to the 10th cent. BCE and contemporary with the founding of the Jerusalem temple. The "Cultic Structure" consists of a room some 25 feet square in a residential area, containing an olive press; a cistern; a bin, a basin, and trough; a hearth and an oven; ceramic vessels; iron knives; a bowl full of astragali (sheep/goat knuckle bones) for casting lots; a mold for making female figurines; and, two remarkable terra cotta offering stands with elaborate iconography, some motifs clearly connected with Asherah the "Lion Lady". In particular, the mold for mass-producing figurines suggests that this shrine may have served the whole village (Zevit 2001, pp. 235-37, 318-25; Dever 2005, pp. 151-55, 209-352; Albertz and Schmitt 2012, pp. 169-72).

"Cult Room 65" at 'Ai, north of Jerusalem, belongs to the 12th cent. BCE early Israelite settlement. It was a small mudbrick structure with low benches around the walls. Specialized cult vessels were in front of a low altar, and on the altar was a large circular fenestrated terra cotta offering stand, the windows for wafting incense, and the top with provision for a removable offering bowl. The stand is unique; around the bottom, below the fenestrations, are several clear, protruding human feet. While orthodox religion according to the Second Commandment forbids any representation of an "invisible Yahweh"; in less sophisticated circles one might at least depict his foot-a visible symbol of his cultic presence (Zevit 2001, pp. 153-156; Dever 2005, pp. 112-13; Albertz and Schmitt 2012, pp. 74-76).

\subsection{Household Shrines}

Thanks to the growing attention that is paid to the archaeological investigation of domestic areas, and especially women's roles in religious practices as in effect the de facto priests, we now have a number of Israelite household shrines.

At Megiddo, "Cult Corner 2081" of the 10th cent. Str. VA/IVB was located in the entrance hall of a large, well-constructed building. The area contained small four-horned incense altars; terra cotta offering stands; numerous ceramic vessels, some "exotic" in nature; a stone offering table; stone mortars and pestles; a bowl containing sheep/goat astragali; and, quantities of burned grain. These implements clearly reflect the use of animal and food offerings, and possibly communal feasting.

In Jerusalem, literally under the shadow of the Temple, a 7th cent. BCE domestic house on the Ophel Hill revealed a domestic shrine in Area G (L. 976) that contained miniature stone altars; grinding stones; chalices, cooking pots, and other vessels; horse-and-rider figurines; arrowheads; a ring; and, a stone weight. Additionally, from this house was a collection of bullae, or clay signet-ring impressions from the seals of papyrus scrolls (Shiloh 1986).

At Lahav (Tel Halif) in the southern Judean hillcountry, a house that ended in the 701 BCE Assyrian destruction yielded an almost intact domestic inventory. In one corner of the typical pillar-courtyard ("four-room") house (Room G 8005) were stone altars; a fenestrated offering stand; a fragmentary female figurine; and, numerous storage and cooking vessels. Elsewhere, similar items suggest that many houses possessed such cult corners (Hardin 2010, pp. 124-60; Albertz and Schmitt 2012, pp. 134-36). 
Many of the 9th-8th cent. BCE Beersheba houses produced evidence of domestic shrines, as witnessed by cultic vessels; small stone altars; animal and human female figurines; amulets and beads; cylinder seals; and, ostrich eggs (Aharoni 1973, passim).

\subsection{Shrines at Forts}

We have already discussed the temple at Arad, which is best considered, not as a "household shrine", but as a place of worship incorporated into a small hilltop fort, where probably only a few conscripted soldiers were in residence. Nevertheless, the rites of worship were probably the same as those of the families from which they came-perhaps given a special concern for personal survival, when considering the implicit dangers of being posted at this isolated border fort.

A unique sanctuary and shrine as an integral part of a fortress-cum-caravansevai (way-station) and pilgrim site is Kuntillet 'Ajrûd (Horvat Teman), in the remote southwestern Sinai desert. This remarkable 8th cent. BCE site was discovered in the late 19th cent., but it was not excavated until the 1970s, and it was only fully published in 2012.

The shrine comprises two long narrow rooms flanking the double-entryway gate, entered only via the gate threshold. These chambers feature low mudbrick benches; plastered walls; and, a favissa partitioned off beyond the back wall. There were few objects found in these two rooms, but on the plastered walls here and in the adjoining courtyard there were numerous painted Hebrew inscriptions, many of them with accompanying pictorial representations on two large storejars.

These inscriptions, although best perhaps considered as graffiti, constitute our largest corpus of non-biblical liturgical Hebrew texts. Many are blessing formulae, but they invoke, not only the name of Yahweh, but also of El, Ba'al, and Asherah.

The pictorial scenes include a lion and an iconic tree-with both symbols directly connected with the goddess Asherah. Another scene depicts a half-nude female, sitting on the sort of lion throne that elsewhere is principally associated with deities. The accompanying Hebrew inscription is a blessing formula for someone deceased that ends with the phrase "May X be blessed by Yahweh of Samaria and his Asherah".

Some scholars have taken the Hebrew term 'ašerah to simply refer to a tree-like symbol that is often associated with Asherah, not the goddess herself. However, here reading is forced, especially if the seated female depicted next to the inscription represents Asherah. To be sure, of the 40 or so times the word 'ašerah occurs in the Hebrew Bible, most do refer to a symbol of Asherah, a tree, or a wooden pole that should be chopped to pieces and burned. However, in at least five or six passages, the term 'ašerah is associated with the well known male deity Ba'al. Thus, we have "Ba'al and Asherah;" and if Ba'al is a deity here, so is Asherah (Meshel 2012; cf. Dever 1984; Olyan 1998; Hadley 2000; Becking 2001; Dever 2005, pp. 160-67; Zevit 2001, pp. 374-79).

\subsection{Cult Paraphernalia}

There are various combinations of cult paraphernalia at all the foregoing sacred places. Many of these objects functioned in ways whose meanings we can infer. The small stone altars, for instance, would have been used for food and drink offerings of the sort that are well attested in both the Hebrew Bible and Canaanite lore. Additionally, the belief or rationale behind such actions is clear: the gods have given us bountiful crops and increasing flocks, so we are obligated to return a symbolic portion. We have a few large stone altars, for animal sacrifice, such as those at Dan, where in the small shrine there are iron shovels for clearing away the ashes on the altar. However, animal sacrifice would have been costly and thus relatively rare in most rural homes.

Among the many objects that were found in the smaller shrines and domestic cultic places are quantities of storejars, chalices, and cooking pots, along with burned bones. This leads us to suppose that, in feeding the gods, one could enjoy the feast themselves, not just priests (as in the Hebrew Bible). This could then be a form of sympathic magic: insuring continued prosperity, in the company of its givers (London 2011). 
Other kinds of offerings and rites can be reconstructed from the artifacts that we have. The small four-horned altars have been shown to have been used principally for burning incense, another act that was thought to please the gods.

The large circular terra cult stands, often fenestrated and with a receptacle at the top for placing a small removable bowl, are clearly for incense and food-drink offerings.

Another kind of offering is a libation in which liquids, like water or wine (and perhaps milk), were ceremoniously poured out in the presence of the gods. This practice is illustrated by several kernoi, or "trick-vessels". A bowl has a hollow ring for a rim, to which are attached several animal heads and other symbolic objects (pomegranates). When the bowl is filled then tilted back and forth, one head can drink up the liquid while the other acts as a spout to pour it out. These kernoi derive from Philistia and are also known in Cyprus; but later, they were freely adopted in the Israelite cult (Dever 2001b).

The female terra cotta figurines are probably the most significant artifacts, but also the most enigmatic. We have more than 2000 of them, from all sorts of contexts: shrines, tombs, and especially in household assemblages. There are three principle types: (1) a nude figure holding a circular object at the breast; (2) a nude figure with a mold-made head, cupping prominent breasts; and, (3) a similar but cruder figure with the head made simply by pinching the clay.

The first type appears as early as the 10th cent. BCE; and, the circular object could be interpreted either as a sun disc, a mold-made cake, or a frame drum. The second and third types typically only appear in Judah in the late 8th-early 6th cent. BCE, during the Assyrian campaigns. These are female figurines often called "fertility figures". Albright dubbed them dea nutrix figurines. Nowadays, political correctness prefers simply to invoke notions of "plenty".

The fundamental question is identity and function: do these female figurines represent the familiar goddess Asherah; or, are they simply votives, human figures in effect symbolic "stand-ins" of the goddess? Scholarly opinion is divided, but the figurines are increasingly directly identified with the goddess herself. In this case, it would clearly be the old Canaanite mother goddess Asherah, the only female goddess that is recognized in the Hebrew Bible, whose cult we now know was widespread. The fierce denunciation of her by the biblical writers is ample evidence of the reality.

In any case, these female figurines have something to do with women soliciting the help of the goddess in conceiving bearing and nurturing babies-the ultimate and difficult task of surviving. This is what religion in the ancient world was all about for most folk: not orthodox theology, but myth and magic. As one observer has said: these are "prayers in clay" (Zevit 2001; c.f. further Kletter 1996; Hadley 2000; Meyers 2007; Darby 2014).

A final class of cultic objects commonly occur principally with burials. In tombs that are typically in the south in the 8th-7th cent. BCE, which are house-like rock-cut chambers, we have such items as valuables from every day life, such as stone and bronze tools; pottery vessels of all kinds, including lamps; various kinds of amulets; and, sometimes miniature furniture like tables and chairs. These artifacts underline the fact that these are family tombs, which have been repeatedly used for generations. In the Hebrew Bible the dead are said to have been "gathered to the fathers". It has been suggested that families may have periodically visited the tombs to feast and "feed the dead", but there is little evidence for such practices. In any case, there is some sense that the dead linger on, at least in living memory (Lewis 1989; Bloch-Smith 1992; Schmidt 1994; Osborne 2011).

\subsection{Pictorial Representations}

One aspect of phenomena that are associated with cult places and practices has often been overlooked, that is, iconography, or symbols that convey meaning through pictorial representations. The neglect may have stemmed from taking the Hebrew Bible's Second Commandment at face value: there was no art in ancient Israel, because any pictorial representation was expressly forbidden.

However, we now know that, while ancient Israelite culture was relatively aniconic when compared with that of her neighbors, there were occasional uses of visual symbols that would constitute art, and art often has connotations for religion. We have already discussed the female figurines as icons 
of some sort; and, the few naoi we have are also relevant. The "proto-Ionic" capitals at several sites employ vegetal motifs. Engraved ivory inlays from several sites borrow motifs from Phoenician art, often retaining older Canaanite concepts. The cult stand at Taanach certainly constitutes art of some sophistication. Finally, we have elaborate pictorial scenes at Kuntillet 'Ajrûd and, even though they are unique thus far, it is reasonable to expect other such discoveries. However, ancient Israelite iconography is best reflected in the numerous seals and seal impressions that we have.

There is now a considerable literature on glyptic art, with much of it stemming from the influence of the "Freibourg school", biblicists, who are also art historians. Thus, one of the most recent syntheses of the archaeological data on Israelite religion devotes a great deal of space to seals and seal impressions, not only for the personal names and offices that they contain, but also for symbols that have religious connotations (Albertz and Schmitt 2012).

Most of the symbols are borrowed of course, principally Egyptian and Mesopotamia. They reveal, in particular, how easily such "pagan" symbols—often associated with foreign deities-were introduced into the Israelite cult. Moreover, it has been shown that both the epigraphic data and the iconography of these seals are conspicuously lacking in any of the central theological themes of the Hebrew Bible (Schroer 1987; Keel 1997; Keel and Uehlinger 1998; and especially Albertz and Schmitt 2012, influenced by the "Freibourg school").

\section{Comparing the Biblical Ideal with the Archaeological Reality}

From the foregoing summary of Iron Age material culture remains, we have drawn a portrait, if not of ancient Israel religious beliefs, then of actual practices throughout Israel's 600-year history. The question is how does that portrait compare with the biblical portrait-that is, what if anything does the archaeological evidence add to our understanding?

The answer may lie in certain disconnects, places where the archaeological evidence, taken as primary here, is at variance with the biblical portrait, or it even flatly contradicts it. One instance is obvious. In the Hebrew Bible, monotheism is the norm, the only approved practice of worship, and said to have been already ordained with the Mosaic covenant with Yahweh at Sinai. However, the archaeological data now accepted by most scholars makes it clear that, in practice, most of the Israelite population practiced polytheism (or monolatry) from the settlement horizon to the exile. Only during the return of the survivors to Judah in the late 6th cent. BCE, the Persian era, did monotheism finally triumph — and that to be a disaster for the lesson to be learned. The old gods had finally failed; but, for centuries they had been adequate.

When the prophet Jeremiah rebuked the exiles in Egypt for "baking cakes for the Queen of Heaven", they replied that it was working just fine for them (Jer. 44:15-23). Additionally, most scholars now identify the Queen of Heaven as Asherah (not "Astarte", as previously).

Another tacit recognition of non-Yahwistic practices is seen in a protest of the prophet Ezekiel, who declares: "Your origin and your birth are of the land of the Canaanites; your father was an Amorite, and your mother a Hittite" (Ezek. 16).

There are other biblical passages that acknowledge the plurality of deities. In Genesis chapter 1, it said that the gods (plural in the Hebrew) declare: "Let us make mankind in our image, male and female". In the Ten Commandments, Yahweh says: "Do not have any other gods before me"; but the Hebrew text reads 'al pĕnāy, literally "in my face". There are other gods; but, you should not insult Yahweh by throwing them up in his face. In these and other biblical passages where we see "feminine" aspects of Yahweh, there may be a way of reconciling the apparent contradictions of text and artifact, that is, a way of deconstructing the biblical narrative.

In several cases, our archaeological data compliment rather than contradict the biblical portrait. The various animal, food, drink, and incense offerings that we see all comport well with biblical injunctions; but, they should only be practiced in Jerusalem under priestly supervision.

Does the more fully fleshed out portrait here, based on archaeological data, mean that we no longer need the biblical text? That is not the case. For one thing, while archaeology enables us to perform 
some forms of history-writing, such as socio-economic, cultural, and technological history, it is poorly equipped to undertake most intellectual history, since we typically lack texts. (That does not mean, as some sceptics maintain, that archaeology is "mute"). For a history of many of the main ideas about religion, we will always need the biblical texts, however limited. Fortunately, we are now discovering more and more non-biblical texts (for the non-biblical texts, see Ahituv 2008; Rollston 2010).

It must also be acknowledged that, while archaeology illuminates many religious practices more effectively than the Bible, there are often commonplace practices that we may assume, but that are not reflected in the archaeological record and not likely to be. These would include: circumcision; other rites of passage; prayers, songs, incantations, and other sayings; and, perhaps many rituals that we may imagine, whether attested in the Hebrew Bible or not.

These caveats lead us to the conclusion that, while the newer and more accurate information provided by archaeology could be helpful, it may not be essential, at least for many believers. They may sometimes seek "proofs", as were expected in the early days of the "Biblical archaeology" movement. However, in the end, literalists will manage without hard evidence by viewing the Bible through the eyes of faith. After all, many religions, for which we have no archaeological (that is, truly historical) data, do survive, and flourish. However, despite its limitations, archaeology is of some value, for many archaeologists do not hesitate to reconstruct prehistoric religion, even though we have no textual evidence.

\section{Conclusions}

Here, we have asked with reference to religion: What can archaeology do; and, what can it not do? We have stressed that archaeology's main contribution to the study of ancient Israelite religion is to provide a "real-life" context, for both the biblical text and its ideals, as well as for widespread religious practices that may not always be in accordance. However, even the most comprehensive archaeological data cannot explain, much less legitimize, Scripture and the religion it enshrines. Archaeology is descriptive, not prescriptive.

\section{Notes}

The general literature on archaeology and cult is beyond our purview here. Many of the recent discussion are part of the "archaeology of mind", "cognitive", or "cognitive-processsual" movements in the post-processual era (that is, since the 1990s). See (Hodder 1988; especially Renfrew 1982; Renfrew 1985; Renfrew 1994; Renfrew 2007; Renfrew et al. 1994; Bell 1997; Kyriakidis 2007. See also literature on "history from things", as Kingery 1996). Nevertheless, specific case-studies where there newer models have proven to be superior in "reading the past" are relatively rare.

Funding: This research received no external funding.

Conflicts of Interest: The author declares no conflict of interest.

\section{References}

Ackerman, Susan. 1992. Under Every Green Tree: Popular Religion in Sixth-Century Judah. HSM 46. Atlanta: Scholars Press.

Aharoni, Y. 1973. Beer-Sheba I. Tel Aviv: Tel Aviv University.

Ahituv, Shmuel. 2008. Echoes from the Past: Hebrew and Cognate Inscriptions from the Biblical Period. Jerusalem: Carta. Albertz, Rainer, ed. 2014. Family and Household Religion: Toward a Synthesis of Old Testament Studies, Archaeology, Epigraphy, and Cultural Studies. Winona Lake: Eisenbrauns.

Albertz, Rainer, and Rüdiger Schmitt. 2012. Family and Household Religion in Ancient Israel and the Levant. Winona Lake: Eisenbrauns.

Arie, Eran. 2008. Reconsidering the Iran Age II Strata at Tel Dan: Archaeological and Historical Considerations. Tel Aviv 35: 6-64. [CrossRef] 
Barr, James. 2000. History and Ideology in the Old Testament: Biblical Studies at the End of a Millennium. Oxford: Oxford University.

Becking, Bob, ed. 2001. Only One God? Monotheism in Ancient Israel and the Veneration of the Goddess Asherah. New York: Sheffield Academia.

Bell, Catherine M. 1997. Ritual: Perspectives and Dimensions. Oxford: Oxford University.

Berlinerblau, Jacques. 1996. The Vow and Popular Religious Groups of Ancient Israel: A Philological and Sociological Inquiry. JSOT Supp 210. Sheffield: Sheffield University.

Binford, Lewis R. 1982. Meaning, Inference and the Material Record. In Ranking, Resource and Exchange: Aspects of Early European Society. Edited by Collin Renfrew and Stephen J. Shennan. Cambridge: Cambridge University, pp. 160-63.

Biran, Avraham. 1994. Biblical Dan. Jerusalem: Israel Exploration Society.

Bloch-Smith, Elizabeth. 1992. Judahite Burial Practices and Beliefs About the Dead. JSOT/ASOR Monograph Series 7; Sheffield: JSOT.

Bloch-Smith, Elizabeth. 2002. Solomon's Temple: The Politics of Ritual Space. In Sacred Time, Sacred Space: Archaeology and the Religion of Israel. Edited by Barry M. Gitlen. Winona Lake: Eisenbrauns, pp. 83-94.

Bodel, John, and Saul M. Olyan, eds. 2008. Household and Family Religion in Antiquity. Malden: Blackwell.

Collins, John J. 2005. The Bible After Babel: Historical Criticism in a Postmodern Age. Grand Rapids: Eerdmans.

Darby, Erin D. 2014. Interpreting Judean Pillar Figurines: Gender and Empire in Judean Apotropaic Ritual. FAT 2:69. Tübingen: Mohr Siebeck.

Dever, William G. 1984. Asherah, Consort of Yahweh? New Evidence from Kuntillet Ajrud. Bulletin of the American Schools of Oriental Research 255: 27-37. [CrossRef]

Dever, William G. 2001a. What Did the Biblical Writers Know and When Did They Know It? What Archaeology Can Tell Us about the Reality of Ancient Israel. Grand Rapids: Eerdmans.

Dever, William G. 2001b. Iron Age Kernoi and the Israelite Cult. In Studies in the Archaeology of Israel and Neighboring Lands. Edited by Samuel R. Wolf. Chicago: Oriental Institute, University of Chicago, pp. 119-31.

Dever, William G. 2005. Did God Have a Wife? Archaeology and Folk Religion in Ancient Israel. Grand Rapids: Eerdmans.

Dever, William G. 2017. Beyond the Texts: An Archaeological Portrait of Ancient Israel and Judah. Atlanta: SBL Press. Geertz, C. 1973. The Interpretation of Cultures. New York: Basic Books.

Gress, David. 1998. From Plato to NATO. The Idea of the West and Its Opponents. New York: Free Press.

Hadley, Judith M. 2000. The Cult of Asherah in Ancient Israel and Judah: Evidence for a Hebrew Goddess. University of Cambridge Oriental Publications 57. Cambridge: Cambridge University Press.

Hardin, James Walker. 2010. Households and the Use of Domestic Space at Iron II Tell Halif: An Archaeology of Destruction (Lahav II). Winona Lake: Eisenbrauns.

Herzog, Zeev. 2001. The Date of the Temple at Arad: Reassessment of the Stratigraphy and the Implications for the History of Religion in Judah. In Studies in the Archaeology of the Iron Age in Israel and Jordan. JSOTS up 331. Edited by Amihai Mazar. Sheffield: Sheffield Academic Press, pp. 156-78.

Herzog, Zeev. 2002. The Fortress Mound at Tel Arad: An Interim Report. Tel Aviv 29: 3-109. [CrossRef]

Hodder, Ian. 1988. Reading the Past: Current Approaches to Interpretation in Archaeology. Cambridge: Cambridge University.

Holladay, John S. 1987. Religion in Israel and Judah under the Monarchy: An Explicitly Archaeological Approach. In Ancient Israelite: Essays in Honor of Frank Moore Cross. Edited by Patrick P. Miller, Paul D. Hanson and S. Dean Macbride. Philadelphia: Westminster John Knox, pp. 249-99.

Keel, Othmar. 1997. The Symbolism of the Biblical World: Ancient Near Eastern Iconography and the Book of Psalms. Winona Lake: Eisenbrauns.

Keel, Othmar, and Christoph Uehlinger, eds. 1998. God, Goddesses, and Images of God in Ancient Israel. Minneapolis: Fortress Press.

Kingery, W. David, ed. 1996. Learning from Things: Method and Theory of Material Culture Studies. Washington: Smithsonian Institution.

Kletter, R. 1996. The Judean Pillar Figurines and the Archaeology of Asherah. Oxford: BAR International Series.

Kyriakidis, Evangelos, ed. 2007. The Archaeology of Ritual. Cotsen Advanced Seminar 3. Los Angeles: Cotsen Institute of Archaeology, University of California, Los Angeles.

Lewis, Theodore J. 1989. Cults of the Dead in Ancient Israel and Ugarit. HSM 30. Atlanta: Scholars Press. 
London, Gloria. 2011. A Ceremonial Center for the Living and the Dead. Near Eastern Archaeology 74: $216-25$. [CrossRef]

Meshel, Zeev. 2012. Kuntillet 'Ajrud (Horuat Teman): An Iron Age II Religious Site on the Judah-Sinai Border. Jerusalem: Israel Exploration Society.

Meyers, Carole L. 1992. Temple, Jerusalem. In Anchor Bible Dictionary. Edited by David Noel Freedman. New York: Doubleday, vol. 6, pp. 350-69.

Meyers, Carole L. 2007. Terra Cottas without Texts: Judean Pillar Figurines in Anthropological Perspective. In To Break Every Yoke: Essays in Honor of Marvin Chaney. Edited by Robert B. Coote and Norman K. Gottwald. Sheffield: Sheffield Phoenix, pp. 115-30.

Monson, John. 2000. The New 'Ain Dara Temple: Closest Solomonic Parallel. Biblical Archaeology Review 26/3: 20-35.

Monson, John. 2005. Solomon's Temple. In Dictionary of the Old Testament Historical Books: A Compendium of Contemporary Scholarship. Edited by Bill T. Arnold and Hugh G. M. Williamson. Downers Grove: Intervarsity Press, pp. 929-35.

Na'aman, Nadar. 2002. The Abandonment of Cult Places from the First Temple Period. Ugarit-forschungen 34: 585-602.

Olyan, Saul M. 1998. Asherah and the Cult of Yahweh in Israel. SBLMS 34. Atlanta: Scholars Press.

Osborne, James F. 2011. Secondary Mortuary Practice and the Bench Tomb: Structure and Practice in Iron Age Judah. Journal of Near Eastern Studies 70: 35-53. [CrossRef]

Renfrew, Colin. 1982. Towards an Archaeology of Mind: An Inaugural Lecture Before the University of Cambridge on 30 November 1982. Cambridge: Cambridge University.

Renfrew, Colin. 1985. The Archaeology of Cult: The Sanctuary at Phylakapi. British School of Archaeology at Athens Supplementary Volume 18. London: British School of Archaeology at Athens.

Renfrew, Colin. 1994. Towards a Cognitive Archaeology. In The Ancient Mind: Elements of Cognitive Archaeology. Edited by Colin Renfrew and Ezra B. W. Zubrow. Cambridge: University of Cambridge.

Renfrew, Colin. 2007. The Archaeology of Ritual, of Cult, and of Religion. In The Archaeology of Ritual. Bristol: ISD LLC, pp. 109-22.

Renfrew, Colin, Ezra B. W. Zubrow, and Francoise Audouze, eds. 1994. The Ancient Mind: Elements of Cognitive Archaeology. Cambridge: Cambridge University.

Rollston, Christopher A. 2010. Writing and Literacy in the World of Ancient Israel: Epigraphic Evidence from the Iron Age. ABS 11. Atlanta: Society of Biblical Literature.

Schmidt, Brian B. 1994. Israel's Beneficent Dead: Ancestor Cult and Necromancy in Ancient Israelite Religion and Tradition. FAT 11. Tubinger: Mohr Siebeck.

Schroer, Sylvia. 1987. Israel Gab es Bilder: Nachrichten von darstellender Kunst in Alten Testament. OBO 74. Göttingen: Vandenhoeck \& Ruprecht.

Shiloh, Y. 1986. A group of Hebrew bullae from the City of David. Israel Exploration Journal 36: 16-38.

Tarnas, Richard. 1991. The Passion of the Western Mind: Understanding the Ideas That Have Shaped Our World View. New York: Ballantine.

Van der Toorn, Karel. 1996. Family Religion in Babylonia, Syria, and Israel: Continuity and Change in the Forms of Religious Life. SHANE 7. Leiden: Brill.

Zevit, Ziony. 2001. The Religions of Ancient Israel: A Synthesis of Parallactic Approaches. London: Continuum.

(C) 2019 by the author. Licensee MDPI, Basel, Switzerland. This article is an open access article distributed under the terms and conditions of the Creative Commons Attribution (CC BY) license (http://creativecommons.org/licenses/by/4.0/). 